\title{
THE NEED FOR POWDER CHARACTERISATION IN THE ADDITIVE MANUFACTURING INDUSTRY AND THE ESTABLISHMENT OF A NATIONAL FACILITY\#
}

\author{
J.M. Benson ${ }^{1 *} \& \mathrm{E}$. Snyders $^{2}$ \\ ${ }^{1}$ Material Science and Manufacturing Unit \\ CSIR, South Africa \\ jbenson@csir.co.za \\ ${ }^{2}$ Research and Development \\ Necsa, South Africa \\ ettienne.snyders@necsa.co.za
}

\begin{abstract}
The characteristics of powders used in additive manufacturing can have significant effects on process efficiencies and the quality of the final products. Powder sizes and morphologies need to be optimised for a particular process, and this requires the facilities to perform these measurements as well as provide a quality check on powder batches that are purchased. The establishment of a national powder characterisation facility has been identified by the Titanium Centre of Competence (a DST-funded initiative) as a critical form of support for the development of a South African titanium metal industry. This paper discusses what effect the different powder characteristics can have on the selective laser sintering processes, as well as the state of development of this national facility.
\end{abstract}

\section{OPSOMMING}

Die eienskappe van die poeiers wat gebruik word vir toevoegingsvervaardiging kan ' $n$ noemenswaardige invloed op die prosesdoeltreffendheid en die gehalte van die finale produkte hê. Poeiergroottes en morfologieë moet geoptimeer word vir ' $n$ spesifieke proses en dit vereis dat fasiliteite hierdie metings moet doen. Die gehalte van die poeier lotte moet ook verseker word. Die daarstelling van ' $\mathrm{n}$ nasionale poeier karakteriseringsfasiliteit is deur die Titaan Bevoegdheidsentrum identifiseer as ' $n$ kritiese ondersteuningsmiddel vir die ontwikkeling van ' $n$ Suid-Afrikaanse titaanmetaalindustrie. Hierdie artikel bespreek die effek van verskillende poeiereienskappe op die selektiewe lasersinterprosesse asook die ontwikkeling status van hierdie nasionale fasiliteit.

\# This article is an extension of a paper presented at the $14^{\text {th }}$ Annual International RAPDASA conference held in Bloemfontein, South Africa in October and November 2013.

* Corresponding author 
The characteristics of powder particles, such as size, shape, surface area, porosity, and impurity content, have a direct impact on how the powder behaves during processing. This in turn affects the efficiency, and ultimately the economics, of the manufacture of the final products (Figure 1).

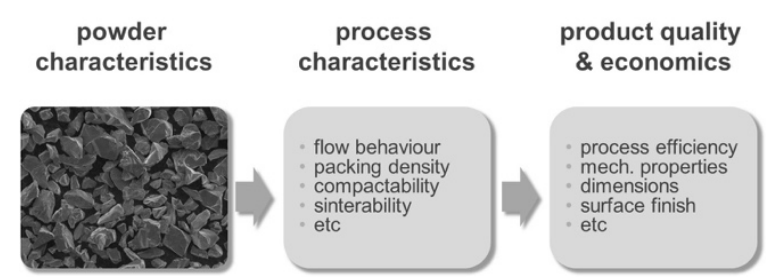

Figure 1: Schematic of the link between powder characteristics and product quality

Measurement of these powder characteristics is thus a vitally important step in the development of the processing methodology, as well as for quality control to ensure consistent output is maintained.

This is particularly important for the additive manufacturing industry, where powder is converted directly (layer by layer) into a functional part. This must be achieved with minimal porosity and dimensional accuracy so that little or no subsequent processing is required.

Consequently, the following factors play a key role and need to be understood and optimised:

- $\quad$ powder flow behaviour for sufficient and consistent feeding/spreading

- powder packing for maximum layer density

- thermal conductivity of the powder layer (and substrate)

- $\quad$ particle porosity (affects sinterability and final part density)

- impurity levels (affect final mechanical properties).

The powder characteristics that are typically measured are summarised in Figure 2.

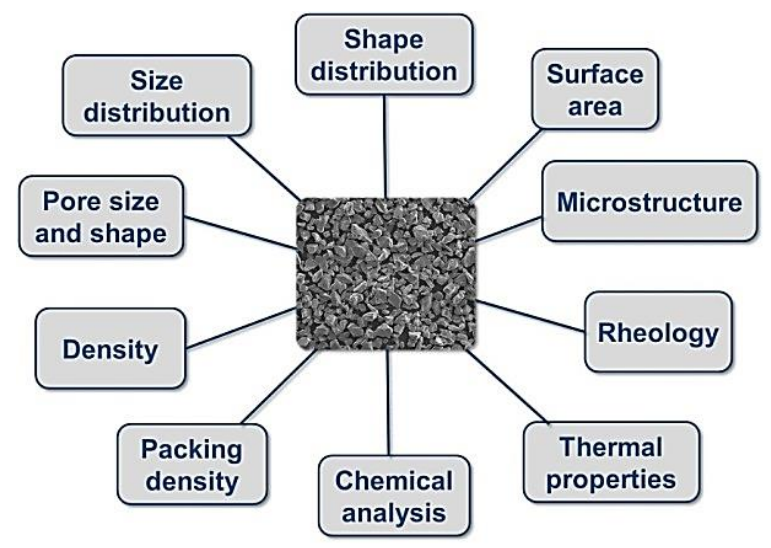

Figure 2: Typical powder characterisation parameters

The correlation between these factors and their impact on the additive manufacturing processes is fairly complex, as there are multiple interactive effects, as indicated in Figure 3. 


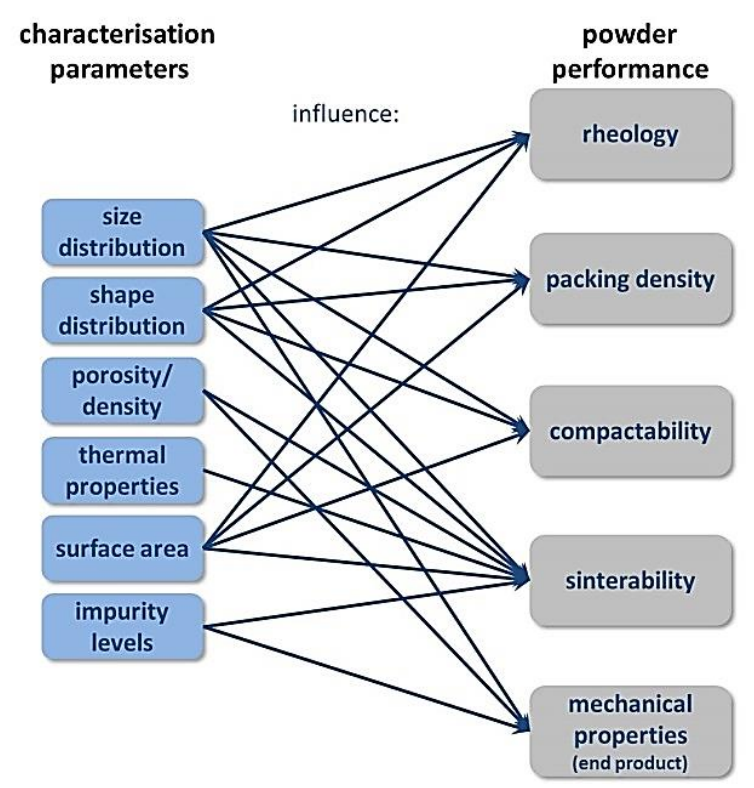

Figure 3: Schematic of the inter-related influence of the various characteristics on the powder behaviour

The documented effects of some of these parameters on laser additive manufacturing processes are discussed in the sections below.

\section{POWDER CHARACTERISTICS AND THEIR IMPACT}

\subsection{Powder size distribution}

Packing density is a measure of how powders naturally compact together without using a compressive load. This is usually determined by a tap density test, where the powder is placed in a graduated cylinder and subjected to repeat taps until a minimum volume is achieved. The density is then related to the inverse of the volume change.

The effect of particle size on the packing density has been measured by Streek et al. [1]; this effect is shown in Figure 4 for tungsten powder. In general, the smaller the particle size, the lower the density that can be achieved. This is due to clumping or agglomeration effects. In practice, powders comprise a range of sizes, and the extent of the spread will also have a significant effect on the packing density. In additive manufacturing, the packing density of the layers determines the subsequent densities after laser sintering.

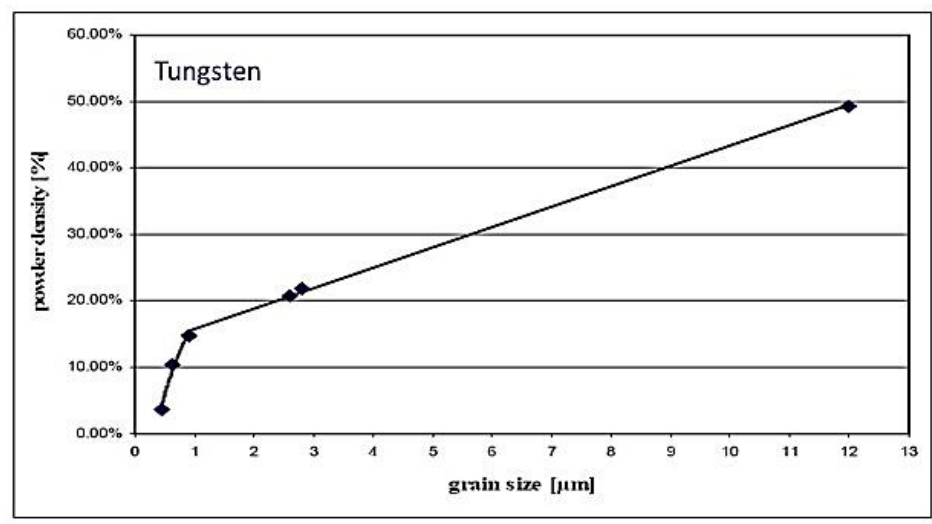

Figure 4: The effect of particle (grain) size on packing density [1] 
Kong et al. [2] investigated the influence of particle size distribution on deposition efficiency and layer thickness in direct metal laser deposition. Inconel 625 powder was used, and the particles were spherical in shape. Five different size distributions were used, as shown in Figure 5.

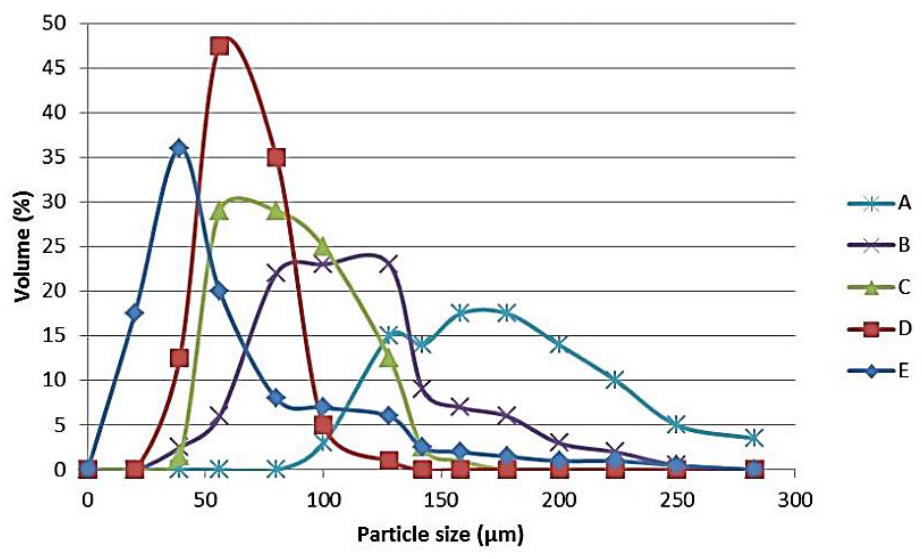

Figure 5: Size distribution of five Inconel 625 powders (redrawn from [2])

The resultant layer thicknesses and deposition efficiencies using these five powders are indicated in Figure 6.

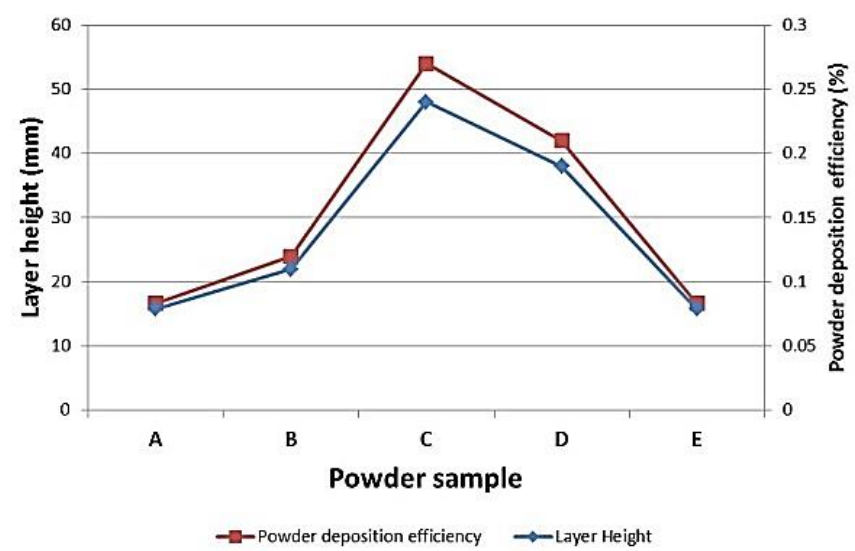

Figure 6: Influence of different Inconel 625 powder size distributions on layer height and deposition efficiency (redrawn from [2])

Clearly powders $C$ and $D$ gave the best results, and these have a mean size distribution between 60 and $80 \mu \mathrm{m}$ (Figure 5).

Karapakis et al. [3] used bimodal powder blends (with varying combinations of coarse and fine particles) to determine how different ratios affected the layer density. They also used a nickel alloy powder with smooth, spherical particles. The resultant layer densities achieved are shown in Figure 7.

Within the parameters of this study, it would appear that the best densities are obtained when the bimodal size difference is large, and the weight ratio of coarse to fine particles is between about 80:20 and 60:40.

This correlates with theoretical predictions [4] as indicated in Figure 8. The calculated densities for varying proportions of bimodal spheres reveal an optimum packing at a ratio of about 75:25 (large:small). 


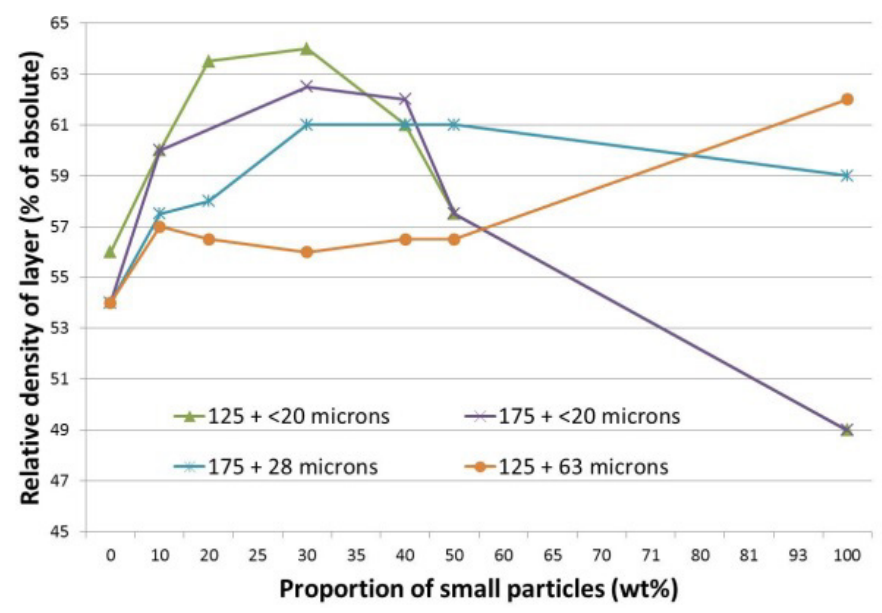

Figure 7: Influence of nickel powder bimodal size ratios on layer densities (redrawn from [3])

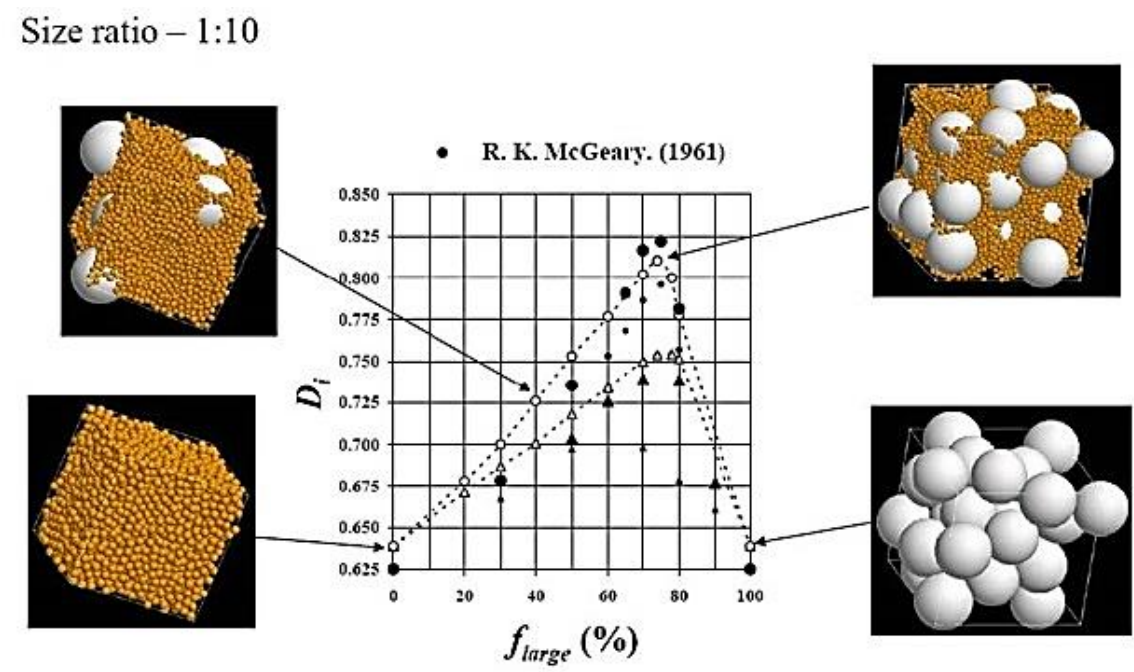

Figure 8: Comparison between the McGeary model and DEM simulations of packing densities for bimodal mixtures of spherical particles [4]

As mentioned, the density of the powder layer has a significant effect on the degree of densification after sintering. This is illustrated by work done on selective laser sintering of aluminium powder [5] that showed a linear correlation between these parameters (Figure 9).

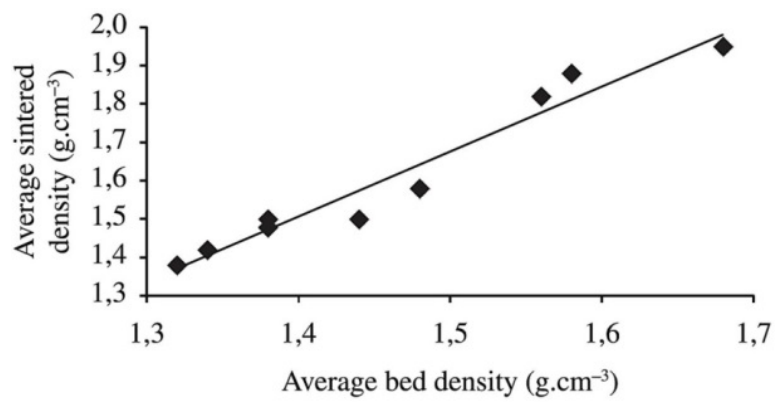

Figure 9: Correlation between average bed density and average sintered density for aluminium powder [5] 


\subsection{Powder shape distribution}

The shape of the powder particles is also a very influential factor and, together with size, can account for most of the behavioural phenomena of powders.

As far as metallic powders are concerned, their shapes can vary considerably, depending on the manufacturing methods used to produce them. Gas atomisation tends to give smooth, spherical particles, whereas precipitation methods can produce dendritic or leaf-like forms. Particles generated by crushing operations have an irregular-to-blocky morphology. Needless to say, these different forms, even if of similar size ranges, will behave significantly differently. Examples of the range in shapes are shown in Figure 10.

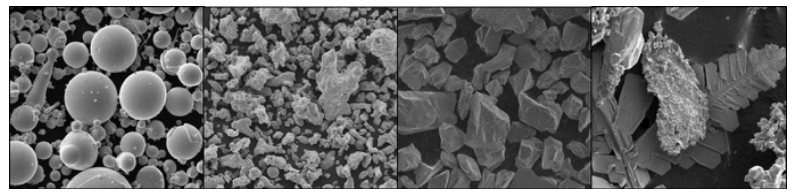

Figure 10: Particle shapes can vary significantly from spherical to dendritic (commercial and CSIR titanium powders)

Shape will determine the efficiency with which the particles can pack together, as measured by the tap density test. This is shown schematically in Figure 11. A unimodal size range is assumed.

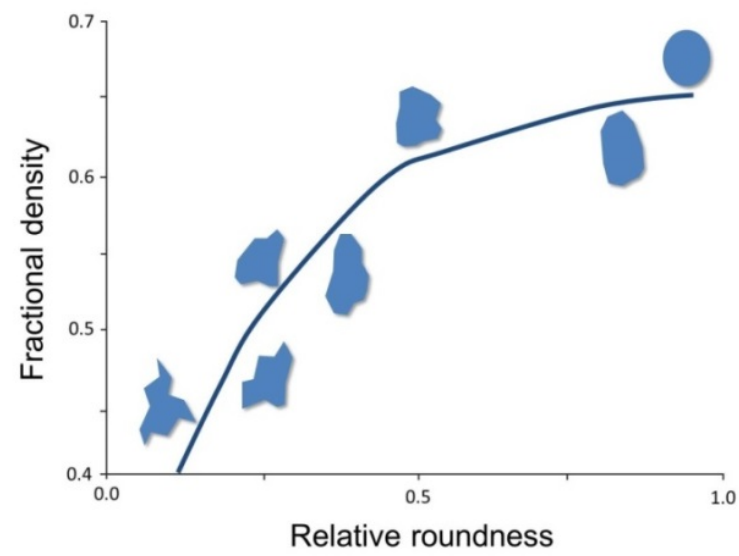

Figure 11: Schematic of effect of shape (degree of roundness) on packing density (redrawn from [4])

The shape may also influence the degree of shrinkage during sintering, and this is likely to be related to the initial packing density. Figure 12 shows the results found for two stainless steel powders that were processed by metal injection moulding (MIM) and subsequently sintered in a furnace [6]. The irregular powder produced the greatest degree of shrinkage. However, the authors postulate that there could be other factors involved, such as entrapped water vapour produced by the high temperature reduction of oxides (in particular $\mathrm{SiO}_{2}$ ).

In a similar vein, two polymeric powders with different shape distributions were selectively laser sintered, and the extent of densification was found to be considerably different [7], as indicated in Figure 13.

Particle shape would also be expected to affect the powder flow behaviour. Cleary and Sawley [8] modelled powder discharge from hoppers and investigated the influence of aspect ratios on these mass flow rates. Their results are shown in Figure 14 for both elliptical and blocky shapes. 


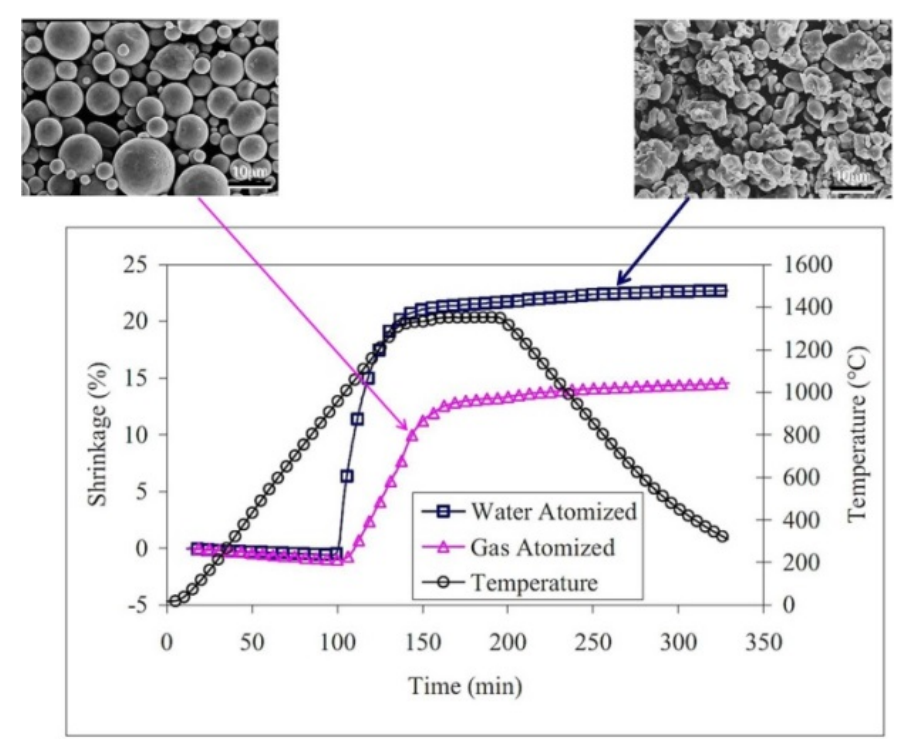

Figure 12: Effect of powder shape on shrinkage during conventional furnace sintering [6]
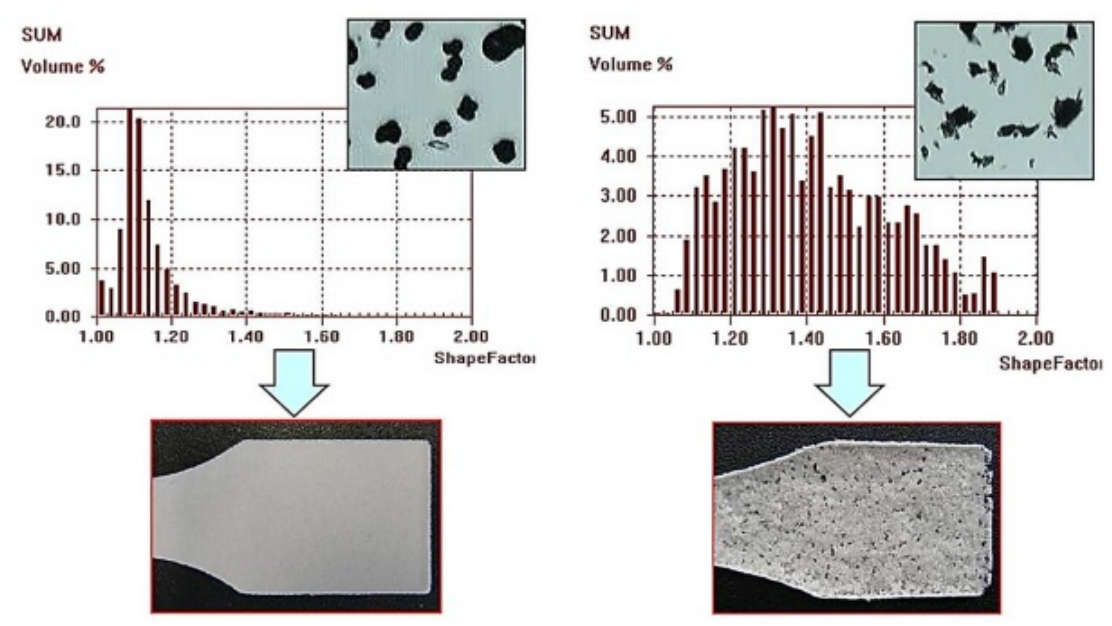

Figure 13: Effect of particle shape distribution of a polymeric powder on the porosity level after selective laser sintering [7]
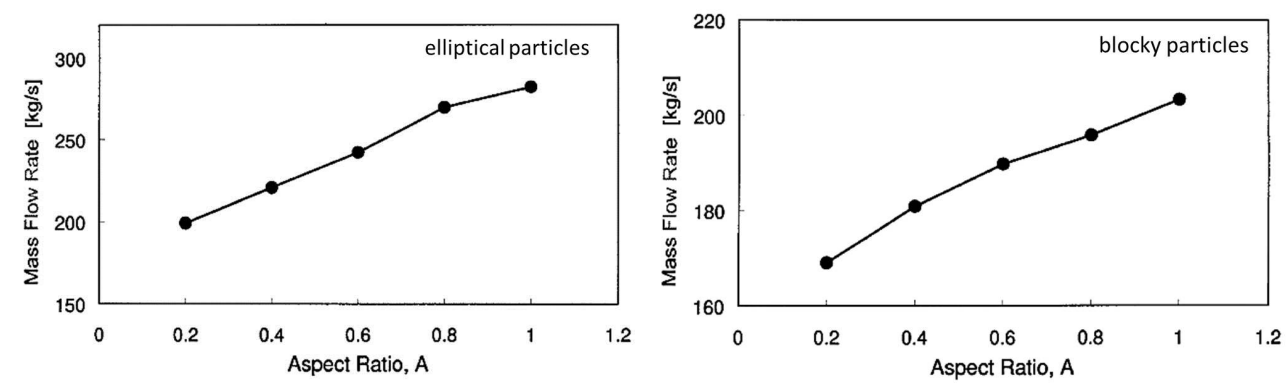

Figure 14: Predicted flow rates of elliptical and blocky particles with varying aspect ratios [8] 
Clearly, as the shape changes from an equiaxed to an elongated form, the rate of flow decreases.

\subsection{Thermal conductivity}

Thermal conductivity is obviously an important factor in laser additive manufacturing systems. The voids between the powder particles are filled with the inert protective gas, which plays a significant role in determining the thermal conductivity of the powder bed. This is due to the thermal conductivity of the gas being appreciably smaller than that of the metal powder (typically $0.0065 \mathrm{~W} / \mathrm{mK}$ vs $400 \mathrm{~W} / \mathrm{mK}$ respectively) [9]. Consequently the powder packing needs to be as high as possible to reduce the void size and maximise the thermal efficiency of the sintering process. As discussed previously, this requires the powder's size and shape distribution to be optimised.

The powder particles themselves often contain some degree of internal porosity, and this may further reduce the rate of heat transfer. No data for particle porosity could be found, but a decrease in thermal conductivity has been measured in bulk copper with varying porosity levels (Figure 15), and so a similar effect might be expected.

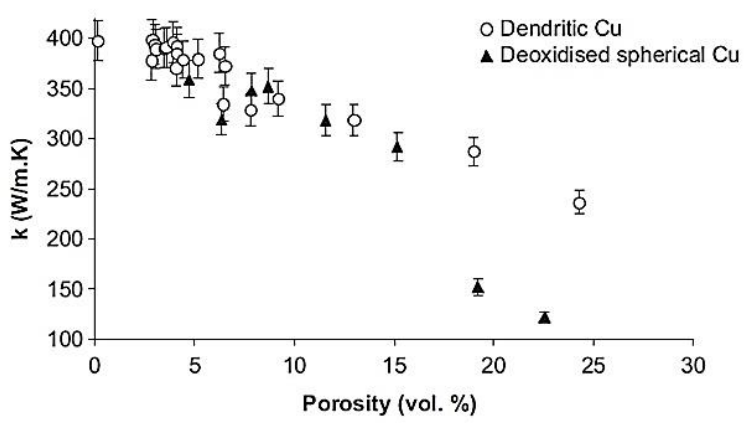

Figure 15: Reduction in thermal conductivity with increasing porosity levels in copper [10]

The size and shape of these pores can be determined, if necessary, using mercury intrusion porosimetry.

\subsection{Impurities}

The presence of impure elements such as oxygen, carbon, nitrogen, or hydrogen can adversely affect the mechanical properties of the final product. In the case of reactive materials like titanium, small quantities of oxygen and nitrogen have a significant impact on strength and ductility (Figure 16).

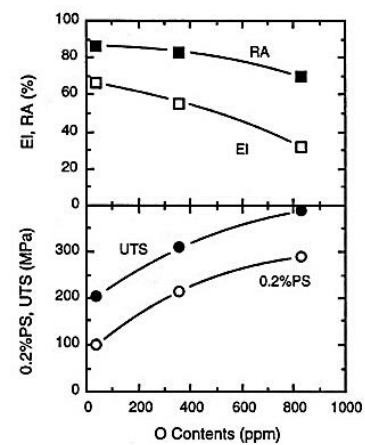

a)

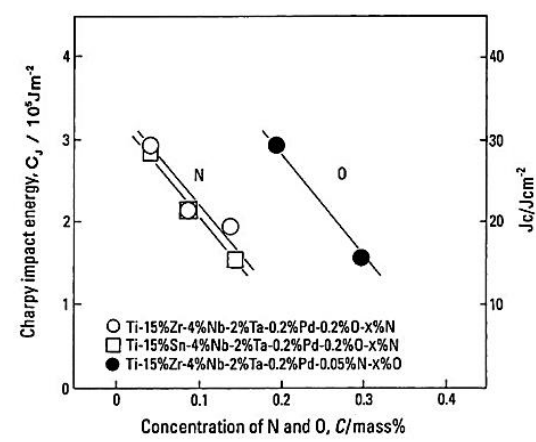

b)

Figure 16: Effect of a) oxygen content on tensile properties of pure titanium [11], and b) oxygen and nitrogen on impact toughness of titanium alloys [12]. 
Pick-up of oxygen and other impurities during processing can occur, so the initial level in the virgin powder must be suitably lower to enable a particular specification in the final product to be met. For instance, certain aerospace applications require the oxygen content in a finished component to be no more than 2000ppm (0.2wt per cent).

\section{ESTABLISHMENT OF A NATIONAL POWDER CHARACTERISATION FACILITY}

The discussion in the previous sections has attempted to illustrate the importance of understanding the powder used in the additive manufacturing process. If a new process or procedure is being developed, the combination of particle size and shape distributions will need to be varied until an optimum result is achieved and a specification is then established. Once in production, subsequent powder batches will need to be analysed to ensure they comply with this specification and that variations are kept to a minimum. All of this will require that there is a local powder characterisation facility capable of serving this industry.

ASTM Standard F2924 - 12 [13] is one of the first international standards developed for additive manufacturing. The need to characterise the powder is stated in Section 7.1:

"The feedstock for this specification shall be metal powder, as defined in Terminology B243, that has the powder type, size distribution, shape, tap density, and flow rate optimized for the process as determined by the component supplier."

In addition, there is now a standard guide specifically addressing the method for characterising powders for additive manufacturing [14].

Furthermore, the advanced manufacturing initiative (AMI), funded by the Department of Science and Technology (DST), is engaged in developing a local primary titanium production facility. This will ultimately supply titanium powder to a downstream titanium industry, including the additive manufacturing sector. Another parallel AMl activity is focusing on a zirconium powder production facility, specifically to support the local nuclear programme. Establishing powder characterisation capabilities in South Africa is thus no longer optional: it is now a necessity.

While some powder analysis is being done in various laboratories in South Africa (either for commercial in-house requirements or at research institutions), there is no accredited laboratory that can address the above needs.

In light of this, facilities for powder measurement are being established at the Council for Scientific and Industrial Research (CSIR) as well as at the powder characterisation laboratory at the Applied Chemistry Department at the South African Nuclear Energy Corporation (Necsa). Details of these are given below.

\subsection{CSIR Characterisation Laboratory}

The CSIR laboratory comprises the following test methods:

Table 1: CSIR laboratory

\begin{tabular}{|c|c|c|}
\hline Method & Equipment & Test/equipment details \\
\hline $\begin{array}{l}\text { Size } \\
\text { distribution }\end{array}$ & $\begin{array}{l}\text { Microtrac Bluewave } \\
\text { analyser }\end{array}$ & Size range: 0.01 to $2000 \mu \mathrm{m}$ \\
\hline $\begin{array}{l}\text { Powder } \\
\text { rheology }\end{array}$ & $\begin{array}{l}\text { Freemantle FT4 } \\
\text { rheometer }\end{array}$ & $\begin{array}{l}\text { Bulk tests: density, compressibility, permeability } \\
\text { Dynamic flow: basic flowability, aeration, } \\
\text { consolidation, flow rate, specific energy } \\
\text { Shear: shear cell, wall friction } \\
\text { Process: segregation, attrition, caking, electrostatics, } \\
\text { moisture, agglomeration }\end{array}$ \\
\hline $\begin{array}{l}\text { Impurity } \\
\text { analysis }\end{array}$ & ELTRA ONH-2000 & $\begin{array}{l}\text { Oxygen: } 0.1 \mathrm{ppm} \text { to } 2.0 \mathrm{wt} \% \\
\text { Nitrogen: } 0.1 \mathrm{ppm} \text { to } 2.0 \mathrm{wt} \% \\
\text { Hydrogen: } 0.01 \text { to } 1000 \mathrm{ppm}\end{array}$ \\
\hline
\end{tabular}


Table 1 (cont.): CSIR laboratory

\begin{tabular}{|l|l|l|}
\hline Method & Equipment & Test/equipment details \\
\hline Thermal analysis & Netzsch STA 449 F3 Jupiter & $\begin{array}{l}\text { DSC/DTA/TGA } \\
\text { Maximum operating temperature: } 1500^{\circ} \mathrm{C}\end{array}$ \\
\hline
\end{tabular}

The purchase of a particle shape analyser was being finalised at the time of writing. Accreditation with ISO 17025 is also being pursued.

\subsection{Powder Characterisation Laboratory, Necsa}

Table 2: Necsa laboratory

\begin{tabular}{|c|c|c|}
\hline Method & Equipment & Test/equipment details \\
\hline Size distribution $^{1}$ & Saturn DigiSizer II Analyzer & Size range: 0.04 to $2500 \mu \mathrm{m}$ \\
\hline Density determination & $\begin{array}{l}\text { Micromeritics AccuPyc } 1340 \\
\text { Automatic Gas Pycnometer }\end{array}$ & $\begin{array}{l}\text { Determination of true volume and } \\
\text { density of solids and powders } \\
10 \text { cc multivolume kit }\end{array}$ \\
\hline $\begin{array}{l}\text { Surface area and pore } \\
\text { structure by gas adsorption }\end{array}$ & Micromeritics Tristar 3000 & $\begin{array}{l}\text { Single and multipoint surface area } \\
\text { Total pore volume } \\
\text { Langmuir surface area and isotherm } \\
\text { reports } \\
\text { t-Plot } \\
\text { BJH adsorption and desorption }\end{array}$ \\
\hline $\begin{array}{l}\text { Pore structure by mercury } \\
\text { intrusion porosimetry (MIP) }\end{array}$ & $\begin{array}{l}\text { Micromeritics Autopore IV } \\
9510\end{array}$ & $\begin{array}{l}\text { Pore size distribution: } 0.003-360 \mu \mathrm{m} \\
\text { One high-pressure ( } 60000 \text { psia max } \\
\text { pressure) and } 2 \text { low-pressure analysis } \\
\text { ports }\end{array}$ \\
\hline
\end{tabular}

\section{REFERENCES}

[1] Streek, A., Regenfuss, P., Ebert, R. \& Exner, H. Laser micro sintering - a quality leap through improvement of powder packing. Last accessed on 13-08-2015 at: http: //sffsymposium.engr.utexas.edu/Manuscripts/2008/2008-27-Streek.pdf.

[2] Kong, C.Y., Carroll, P.A., Brown, P. \& Scudamore, R.J. The effect of average powder particle size on deposition efficiency, deposit height and surface roughness in the direct metal laser deposition process. Last accessed on 13-08-2015 at: www.twi.co.uk/technicalknowledge/published-papers/the-effect-of-average-powder-particle-size-on-depositionefficiency-deposit-height-and-surface-roughness-in-the-direct-metal-las/.

[3] Karapatis, N.P., Egger, G., Gygax, P.-E. \& Glardon, R. Optimization of powder layer density in selective laser sintering. Last accessed on 13-08-2015 at: http://sffsymposium.engr.utexas.edu/Manuscripts/1999/1999-029-Karapatis.pdf.

[4] Hofmann, H. \& Bowen, P. Powder technology: From landslides and concrete to avalanches and chocolate. Last accessed on 13-08-2015 at: http://ltp.epfl.ch/files/content/sites/ltp/files/shared/Teaching/Master/06-

PowderTechnology/PowderTech-02.pdf.

[5] Olakanmi, E.O. 2012. Effect of mixing time on bed density and microstructure of selective laser sintered (SLS) aluminium powders, Materials Research, 15(2), pp. 167-176.

[6] Koseski, R.P., Suri, P., Earhardt, N.B. \& German, R.M. 2005. Microstructural evolution of injection molded gas and water atomized 316 stainless steel powder during sintering. Materials Science and Engineering A, 390, pp. 171-177.

[7] Advanced Additive Manufacturing Powder Analysis, Inspire Irpd. Last accessed on 13-08-2015 at: http: //www.powdershape.ch/products/powdershape-1/documents/spirings2012-short-reportinspire.

[8] Cleary, P.W. \& Sawley, M.L. 2002. DEM modelling of industrial granular flows: 3D case studies and the effect of particle shape on hopper discharge. Applied Mathematical Modelling, 26, pp. 89-111.

[9] Patil, R.B. \& Yadava, V. 2007. Finite element analysis of temperature distribution in single metallic powder layer during metal laser sintering. International Journal of Machine Tools \& Manufacture, 47, pp. 1069-1080.

[10] Vincent, C., J.F. Silvain, J.F., Heintz, J.M. \& Chandra, N. 2012. Effect of porosity on the thermal conductivity of copper processed by powder metallurgy. Journal of Physics and Chemistry of Solids, 73, pp. 499-504. 
[11] Ouchi, C., Lizumi, H. \& Mitao, S. 1998. Effects of ultra-high purification and addition of interstitial elements on properties of pure titanium and titanium alloy. Materials Science and Engineering A, 243, pp. 186-195.

[12] Okazaki, Y., Ito, Y., Ito, A. \& Tateishi, T. 1993. Effect of alloying elements on mechanical properties of titanium alloys for medical implants. Material Transactions, JIM, 34(12), pp. 12171222.

[13] ASTM Standard F2924 - 12. Standard specification for additive manufacturing Titanium-6 Aluminum-4 Vanadium with powder bed fusion.

[14] ASTM Standard F3049 - 14: Standard Guide for Characterizing Properties of Metal Powders Used for Additive Manufacturing Processes. 